\title{
Land-Use Changes the Chemical and Physical Properties of an Oxisol in the Brazilian Cerrado
}

\author{
Raphael Xavier Costa ${ }^{1}$, Joaquim José Frazão ${ }^{2}$, Roriz Luciano Machado ${ }^{1}$, Débora Regina Marques Pereira ${ }^{1}$, \\ Leonardo Mariano do Nascimento ${ }^{1}$, Ana Paula Santos Oliveira ${ }^{1} \&$ Valter dos Santos Marques ${ }^{1}$ \\ ${ }^{1}$ Goiano Federal Institute of Education, Science and Technology, Ceres Campus, Ceres, GO, Brazil \\ ${ }^{2}$ Goiano Federal Institute of Education, Science and Technology, Iporá Campus, Iporá, GO, Brazil \\ Correspondence: Roriz Luciano Machado, Goiano Federal Institute of Education, Science and Technology (IF \\ Goiano), Ceres Campus, GO-154, km 03, 76300-000, Ceres, GO, Brazil. Tel: 55-62-3307-7100. E-mail: \\ roriz.machado@ifgoiano.edu.br
}

Received: June 1, 2020

Accepted: July 7, $2020 \quad$ Online Published: August 15, 2020

doi:10.5539/jas.v12n9p181

URL: https://doi.org/10.5539/jas.v12n9p181

\begin{abstract}
This research aimed to evaluate the effect of different land-uses on physical and chemical properties of Oxisols under cerrado conditions in central region of Goiás, Brazil. The data were analysed in a randomized experimental design in a $4 \times 3$ factorial arrangement with five replications. The land-uses were: 1-Annual crops, 2-Pasture, 3-Sugarcane and 4-Native forest (control). The second factor consisted of three sampling depths: $0-0.05,0.1-0.2$ and $0.2-0.3 \mathrm{~m}$. The physical attributes analysed were: total clay (TC), natural clay (NC), bulk density (BD), particle density (PD), total porosity (TP), degree of flocculation (DF), soil resistance to penetration (SRP), gravimetric water content (\%GWC). Chemicals attributes analized: $\mathrm{pH}$ in water $(\mathrm{pH})$, calcium $(\mathrm{Ca})$, magnesium $(\mathrm{Mg})$, aluminium $(\mathrm{Al})$, potential acidity $(\mathrm{H}+\mathrm{Al})$, potassium $(\mathrm{K})$, phosphorus $(\mathrm{P})$, soil organic matter (SOM), cation exchange capacity $(\mathrm{T})$ and base saturation (V\%). Annual crops showed higher K levels (0-0.3 m) and lower SOM values $(0-0.3 \mathrm{~m}), \mathrm{Ca}$ and $\mathrm{Mg}(0-0.05 \mathrm{~m})$ affecting $\mathrm{T}$ in relation to the forest. The use sugarcane showed higher values of BD, PD and SRP, and smaller values of TP, SOM, P and T. On the other hand, the values of $\mathrm{Ca}$ and $\mathrm{Mg}$ are kept close to those of the control. The attribute $\mathrm{V} \%$ is preserved for annual crops, sugarcane and pasture with values higher than those verified in native forest. The use pasture reduced TP and $\mathrm{P}$ and $\mathrm{Ca}, \mathrm{Mg}$ and $\mathrm{T}$. The land-uses studied reduced soil quality compared to the forest, in descending order were sugarcane $>$ annual crops $>$ pasture.
\end{abstract}

Keywords: soil management and conservation, soil quality, Barro Alto complex, Ceres

\section{Introduction}

The Cerrado is the second largest Brazilian biome in territorial extension, over which the largest conversion of native forest areas to agricultural and/or livestock activities has occurred in recent decades in Brazil. Although this conversion has generated economic progress for this region, the inadequate use of the soil by these economic activities has accelerated the processes of soil degradation.

Several authors have reported that changes in the use and management of Cerrado soils have promoted significant changes in chemical, physical and biological attributes (Hunke, Roller, Zeilhofer, Schröder, \& Mueller, 2015; Silva et al., 2017; Bonetti, Paulinho, Souza, Carneiro, \& Caetano, 2018; Lobato et al., 2018; Dias, Hübner, Nunes, Leandro, \& Xavier, 2019). In addition, these changes in soil properties have been accelerated by the intensification of agricultural systems (Hunke, Mueller, Schröder, \& Zeilhofer, 2014; Moklyachuk, Yatsuk, \& Draga, 2015).

Variations in terms of intensification of agricultural systems are present in the region of Ceres, state of Goiás (Brazil). In this Cerrado region, pastures (native and cultivated), sugar cane cultivation, fruit growing, annual crops (mainly corn, sorghum and soybean) and olericulture (Marques, 2013) predominate. In addition, the soils of this region, in general, have good natural fertility and good water retention capacity; however, they have undulating relief in large part, which hinders agricultural mechanization and favours the occurrence of water erosion. 
Understanding how the intensification of land-use alters the physical and chemical properties of the soil brings relevant information, which allows the prevention of soil degradation and, at the same time, makes agricultural systems more sustainable (Pilatti et al., 2018). In this context, the objective of this work was to evaluate the changes in the chemical and physical properties of the soil under different uses and soil management schemes.

\section{Method}

The work was carried out from August 2013 to July 2014, in the watershed of the Água Azul stream, located in the municipality of Ceres, state of Goiás, Brazil. The watershed is located in the quadrant comprising the following coordinates: $648,153 \mathrm{~m}$ and $650,236 \mathrm{~m}$ West and 8,304,381 $\mathrm{m}$ and 8,301,875 $\mathrm{m}$ south, spindle $22 \mathrm{~L}$ and Central Meridian (MC) of $-51^{\circ}$ WGr (Figure 1). The climate according to Köppen's climatic classification is Aw, that is, savanna or tropical climate with wet and dry seasons-Tropical Seasonal, dry winter, with two well-defined seasons.

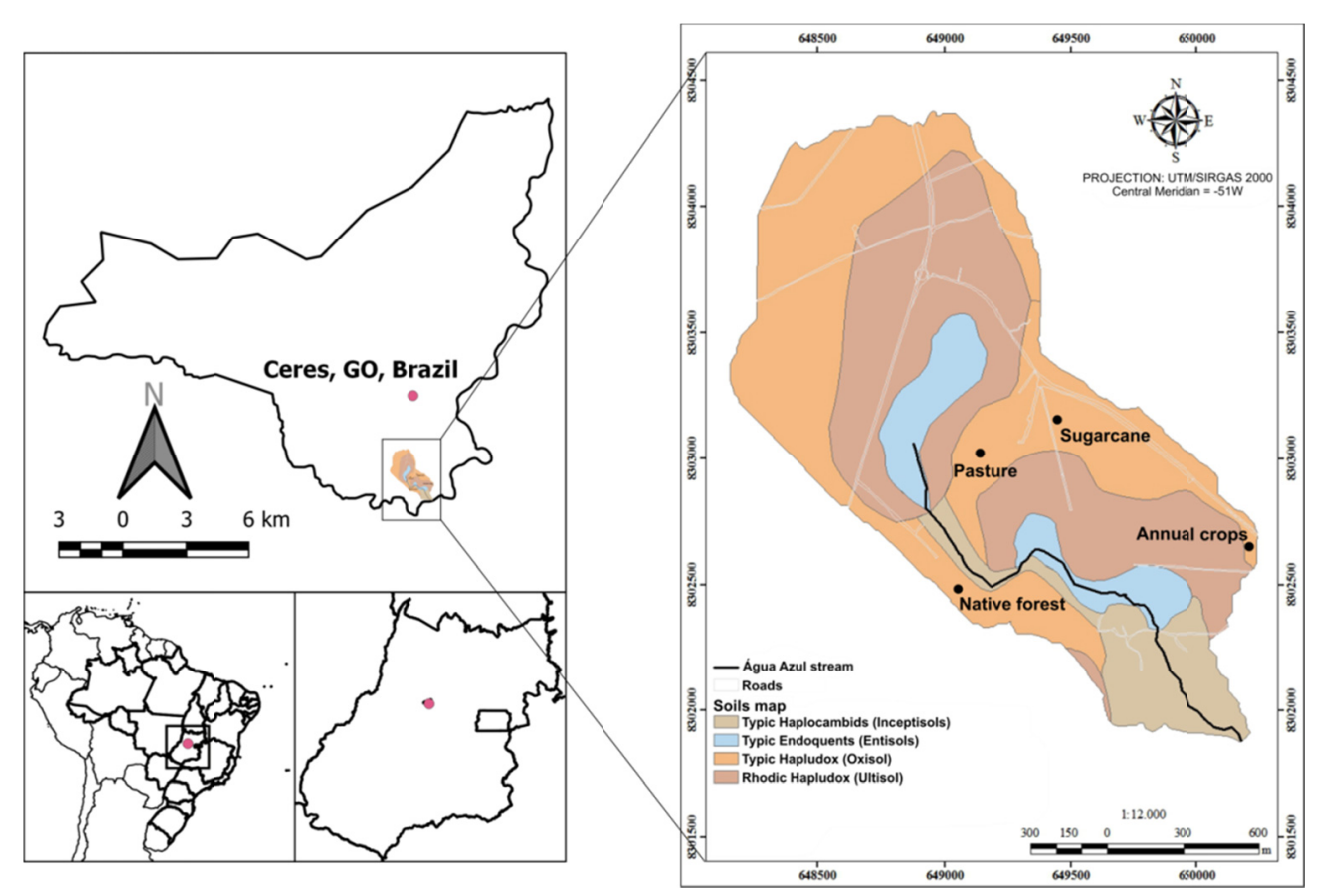

Figure 1. Geographic location and main soil types of study sites. Adapted from Marques (2013).

The experimental design used was completely randomized in a $4 \times 3$ factorial arrangement (four land-uses and three soil depths), with five replications. The land-uses studied were 1) annual crops under conventional cultivation; 2) sugarcane harvested by burning; 3) brachiaria pasture and 4) native forest. These land-uses are detailed in Table 1. The second factor consisted of three soil depths: 0-0.05, 0.10-0.20 and 0.20-0.30 m. 
Table 1. Description of land-use and management of the selected areas

\begin{tabular}{|c|c|}
\hline Land-use & Description \\
\hline Native Forest & $\begin{array}{l}\text { Area under secondary subcaduciferous tropical forest and with little anthropic disturbance today. It is found in the } \\
\text { UTM coordinates: } \mathrm{E}=649,053.1 \mathrm{~m} \text { and } \mathrm{N}=8,302,483.66 \mathrm{~m} \text {, Datum WGS_1984, Zone 22S, Central Meridian-51. } \\
\text { Total area of } 2.13 \text { hectares. }\end{array}$ \\
\hline Annual crops & $\begin{array}{l}\text { Area used predominantly for corn, bean, soybean and sorghum crops for more than } 30 \text { years in the conventional system } \\
\text { with heavy harrow followed or not by level harrow. Soil correction every five years (on average) and application of } 300 \\
\text { to } 500 \mathrm{~kg} \mathrm{ha}^{-1} \text { of NPK to each plantation. It is located in the UTM coordinates: E }=650,208.78 \mathrm{~m} \text { and N }=8,302,657.07 \\
\mathrm{~m} \text {, Datum WGS_1984, Zone } 22 \mathrm{~S} \text {, Central Meridian-51. Total area of } 1.4 \text { hectares. }\end{array}$ \\
\hline Sugarcane & $\begin{array}{l}\text { The area has been used for more than } 15 \text { years with cultivation with manual harvesting and burning. The soil is } \\
\text { corrected and fertilized by means of liming and plastering every } 5 \text { years on average and mineral fertilization. The area } \\
\text { has terraces for erosion control. It is located in the UTM Coordinate System: E }=649,448.00 \mathrm{~m} \text { and } \mathrm{N}=8,303,162.00 \\
\mathrm{~m} \text {, Datum WGS_1984, Zone } 22 \mathrm{~S} \text {, Central Meridian-51. Total area of } 12.17 \text { hectares. }\end{array}$ \\
\hline Pasture & $\begin{array}{l}\text { With more than } 20 \text { years of planting, the brachiaria (Brachiaria brizantha) pasture does not have soil fertility } \\
\text { management except during implantation and presents evidence of overcrowding of animals. It is located in the UTM } \\
\text { Coordinate system: } \mathrm{E}=649,142.00 \mathrm{~m} \text { and } \mathrm{N}=8,303,016.00 \mathrm{~m} \text {, Datum WGS_1984, Zone } 22 \mathrm{~S} \text {, Central Meridian-51. } \\
\text { Total area of } 10.35 \text { hectares. }\end{array}$ \\
\hline
\end{tabular}

The different land-uses were selected in an area under the same soil type, in this case, Typic Hapludox (Oxisol), classified according to the USDA Soil Survey Staff (2014) (Figure 1). In each area corresponding to land-uses, disturbed and undisturbed soil samples were collected to determine, respectively, chemical and physical attributes, at the three depths mentioned. Sampling was performed in a zigzag pattern, with an average distance of 10 meters between collection points (repetitions), with three simple samples per point, from which a composite sample originated (disturbed samples). The chemical and physical analyses of the soil were carried out according to the methodology of Donagema, Campos, Calderano, Teixeira and Viana (2011) with some modifications.

The physical attributes evaluated were total clay (TC), natural clay (NC), degree of flocculation (DF), bulk density (BD), particle density (PD), total porosity (TP), soil resistance to penetration (SRP), and concomitant to this analysis, determination of gravimetric water content (\%GWC), at the same depths. The SRP analysis was carried out using a digital penetrograph (Eijkelkamp model), with 10 samples per plot. TC and NC were determined by the pipette method (Day et al., 1965; modified) after dispersion in water (NC) or $0.1 \mathrm{M} \mathrm{NaOH}$ solution (TC). DF was determined according to the following equation:

$$
D F=[(T C-N C) / T C] \times 100
$$

PD was determined through the volumetric flask method using ethyl alcohol. BD was determined using a cylindrical metal sampler $(0.05 \times 0.05 \mathrm{~m})$, which was oven-dried at $105{ }^{\circ} \mathrm{C}$ and weighed. BD was obtained by the equation:

$$
B D=M s / V S
$$

where, $M s$ is mass of dry soil (g) and, $V s$ is volume of the sampler $\left(\mathrm{cm}^{3}\right)$.

TP was obtained by the equation:

$$
T P=[(P D-B D) / P D] \times 100
$$

The chemical attributes evaluated were $\mathrm{pH}$ in water, phosphorus $(\mathrm{P})($ Mehlich $\mathrm{I})$, potassium $\left(\mathrm{K}^{+}\right)$, calcium $\left(\mathrm{Ca}^{2+}\right)$, magnesium $\left(\mathrm{Mg}^{2+}\right)$, aluminium $\left(\mathrm{Al}^{3+}\right)$, potential acidity $(\mathrm{H}+\mathrm{Al})$, soil organic matter $(\mathrm{SOM})$, base saturation $(\mathrm{V} \%)$ and cation exchange capacity (T). $\mathrm{Ca}, \mathrm{Mg}$ and $\mathrm{Al}$ were extracted with $1 \mathrm{M} \mathrm{KCl}$ and, $\mathrm{P}$ and $\mathrm{K}$ with the Mehlich I solution $\left(0.05 \mathrm{M} \mathrm{HCl}+0.0125 \mathrm{M} \mathrm{H}_{2} \mathrm{SO}_{4}\right)$. P was measured colorimetrically by the molybdenum blue method. Aluminum was measured by titration with $0.025 \mathrm{M} \mathrm{NaOH} ; \mathrm{Ca}, \mathrm{Mg}$ and $\mathrm{Mg}$ by atomic absorption spectroscopy. Potential acidity was extracted with $0.01 \mathrm{M}$ calcium chloride buffered and measured by potentiometry with combined electrode immersed in suspension. SOM was extracted by oxidation with sodium dichromate in sulfuric acid medium, and determined by spectroscopy UV-VIS $(650 \mathrm{~nm})$.

The data were checked for normality and homogeneity of variances of the residuals using the SAEG 4.0 software. Then, analysis of variance (ANOVA) was performed, and when there was an effect of the tested factors (land-use and depth), the averages were compared using the Scott-Knott test $(\mathrm{P}<0.05)$. Pearson's correlation analysis $(\mathrm{P}<$ 0.05 ) between the physical and chemical attributes of the soil was also performed. 


\section{Results and Discussion}

Tables 2 and 3 present summaries of the analysis of variance (ANOVA) for the physical and chemical attributes of the soil, respectively. The different land-uses and soil depth evaluated significantly influenced most of the physical and chemical attributes of the soil. There was a significant interaction of land-use and depth factors for all physical and chemicals soil attributes except, $\mathrm{NC}, \mathrm{DF}$ and $\mathrm{pH}$ with no significant differences for the treatments tested (Table 3).

Table 2. Summary of analysis of variance (ANOVA) of physical attributes of soil under different soil use management and soil depths

\begin{tabular}{llllllllll}
\hline \multirow{2}{*}{ VF } & \multirow{2}{*}{$\mathrm{DF}$} & \multicolumn{9}{c}{ Mean squares } \\
\cline { 3 - 9 } & & $\mathrm{TC}$ & $\mathrm{NC}$ & $\mathrm{DF}_{1}$ & $\mathrm{BD}$ & $\mathrm{PD}$ & $\mathrm{TP}$ & $\mathrm{SRP}$ & $\mathrm{GWC}$ \\
\hline $\mathrm{LU}$ & 3 & $35542.27^{* *}$ & $156.55^{\text {ns }}$ & $87.61^{\text {ns }}$ & $0.23^{* *}$ & $0.04^{* *}$ & $309.62^{* *}$ & $2.35^{\text {ns }}$ & $26.74^{* *}$ \\
$\mathrm{SD}_{\text {general }}$ & 2 & $15051.02^{* *}$ & $245.02^{\text {ns }}$ & $33.97^{\text {ns }}$ & $0.04^{*}$ & $0.01^{\text {ns }}$ & $83.66^{*}$ & $65.68^{* *}$ & $1.09^{\text {ns }}$ \\
LU x SD & 6 & $3959.35^{\text {ns }}$ & $162.28^{\text {ns }}$ & $12.67^{\text {ns }}$ & $0.01^{\text {ns }}$ & $0.00^{\text {ns }}$ & $23.21^{\text {ns }}$ & $3.64^{*}$ & $7.07^{*}$ \\
SD1/LU & 3 & $19063.25^{* *}$ & $226.33^{\text {ns }}$ & $78.11^{\text {ns }}$ & $0.09^{* *}$ & $0.01^{\text {ns }}$ & $130.01^{* *}$ & $1.59^{\text {ns }}$ & $21.40^{* *}$ \\
SD $/$ LU & 3 & $14617.38^{* *}$ & $21.93^{\text {ns }}$ & $14.76^{\text {ns }}$ & $0.08^{* *}$ & $0.02^{* *}$ & $119.08^{* *}$ & $0.73^{\text {ns }}$ & $17.75^{* *}$ \\
SD3/LU & 3 & $9780.33^{*}$ & $232.85^{\text {ns }}$ & $20.07^{\text {ns }}$ & $0.09^{* *}$ & $0.01^{* *}$ & $106.87^{* *}$ & $5.26^{* *}$ & $1.74^{\text {ns }}$ \\
Residue & 48 & 2408.05 & 532.77 & 36.57 & 0.01 & 0.003 & 18.60 & 0.79 & 2.73 \\
\hline CV(\%) & - & 10.71 & 32.79 & 7.19 & 8.12 & 2.07 & 8.76 & 27.77 & 8.43 \\
Average & - & $458.33 \mathrm{~g} \mathrm{~kg}^{-1}$ & $70.38 \mathrm{~g} \mathrm{~kg}^{-1}$ & $84.09 \%$ & $1.26 \mathrm{~kg} \mathrm{dm}^{-3}$ & $2.48 \mathrm{~kg} \mathrm{dm}^{-3}$ & $49.25 \%$ & $3.19 \mathrm{MPa}$ & $19.60 \%$ \\
SE & - & 8.83 & 2.79 & 0.78 & 0.02 & 0.01 & 0.78 & 0.22 & 0.27 \\
\hline
\end{tabular}

Note. VF: variation factor. LU: land-use. SD: soil depth (SD1 $=0-0.05 \mathrm{~m}, \mathrm{SD} 2=0.10-0.20 \mathrm{~m}, \mathrm{SD} 3=0.20-0.30$ $\mathrm{m})$. $\mathrm{CV}(\%)$. Coefficient of variation. SE: standard error. DF: degree of freedom. TC: total clay. NC: natural clay. $\mathrm{DF}_{1}$ : degree of flocculation. $\mathrm{BD}$ : bulk density. PD: particles density. TP: total porosity. SRP: soil resistance to penetration. GWC: gravimetric water content. $\mathrm{ns}=$ not significant; * significant $(\mathrm{P}<0.05)$; ** significant $(\mathrm{P}<$ $0.01)$.

Table 3. Summary of analysis of variance (ANOVA) of chemical attributes of soil under different land-use management schemes and at different soil depths

\begin{tabular}{|c|c|c|c|c|c|c|c|c|c|c|c|}
\hline \multirow{2}{*}{ VF } & \multirow{2}{*}{ DF } & \multicolumn{10}{|c|}{ Mean squares } \\
\hline & & $\mathrm{pH}$ & $\mathrm{Al}$ & SOM & $\mathrm{Ca}$ & $\mathrm{Mg}$ & $\mathrm{K}$ & $\mathrm{H}+\mathrm{Al}$ & $\mathrm{P}$ & $\mathrm{T}$ & $\mathrm{V} \%$ \\
\hline $\mathrm{LU}$ & 3 & $0.18^{\text {ns }}$ & $0.33^{*}$ & $623.33^{* *}$ & $2.39^{*}$ & $0.52^{* *}$ & $11466.67^{* *}$ & $63.20^{* *}$ & $82.40^{* *}$ & $93.28^{* *}$ & $863.87^{* *}$ \\
\hline $\mathrm{SD}_{\text {general }}$ & 2 & $0.17^{\mathrm{ns}}$ & $0.08^{\text {ns }}$ & $453.27^{* *}$ & $3.74^{*}$ & $0.57^{*}$ & $5511.67^{*}$ & $0.79^{\mathrm{ns}}$ & $10.76^{\mathrm{ns}}$ & $12.63^{*}$ & $11.78^{\mathrm{ns}}$ \\
\hline $\mathrm{LU} \times \mathrm{SD}$ & 6 & $0.08^{\text {ns }}$ & $0.08^{\mathrm{ns}}$ & $13.43^{\text {ns }}$ & $1.27^{\mathrm{ns}}$ & $0.08^{\mathrm{ns}}$ & $965.00^{\mathrm{ns}}$ & $3.51^{* *}$ & $10.69^{\mathrm{ns}}$ & $1.35^{\mathrm{ns}}$ & $157.82^{\mathrm{ns}}$ \\
\hline $\mathrm{SD} 1 / \mathrm{LU}$ & 3 & $0.06^{\mathrm{ns}}$ & $0.02^{\mathrm{ns}}$ & $321.84^{* *}$ & $2.96^{*}$ & $0.44^{*}$ & $8125.00^{* *}$ & $6.11^{* *}$ & $60.86^{* *}$ & $19.83^{* *}$ & $35.58 \mathrm{~ns}$ \\
\hline $\mathrm{SD} 2 / \mathrm{LU}$ & 3 & $0.16^{\mathrm{ns}}$ & $0.80^{\mathrm{ns}}$ & $145.01^{* *}$ & $0.80^{\mathrm{ns}}$ & $0.11^{\mathrm{ns}}$ & $2573.33^{*}$ & $28.66^{* *}$ & $24.15^{*}$ & $33.32^{* *}$ & $542.56^{* *}$ \\
\hline $\mathrm{SD} 3 / \mathrm{LU}$ & 3 & $0.11^{\mathrm{ns}}$ & $0.39^{* *}$ & $183.33^{* *}$ & $1.18^{\mathrm{ns}}$ & $0.12^{\mathrm{ns}}$ & $2698.33^{*}$ & $35.45^{* *}$ & $18.77^{\text {ns }}$ & $42.83^{* *}$ & $601.37^{* *}$ \\
\hline Residue & 48 & 0.07 & 0.03 & 16.86 & 0.74 & 0.12 & 785.00 & 0.86 & 6.75 & 1.25 & 59.38 \\
\hline $\mathrm{CV}(\%)$ & - & 4.82 & 84.07 & 17.86 & 23.26 & 25.01 & 45.68 & 18.50 & 71.89 & 10.84 & 14.84 \\
\hline Average & - & 5.66 & $\begin{array}{l}0.22 \\
\text { cmol }_{c} \mathrm{dm}^{-3}\end{array}$ & $\begin{array}{l}22.99 \\
\mathrm{~g} \mathrm{~kg}^{-1}\end{array}$ & $\begin{array}{l}3.70 \\
\mathrm{cmol}_{\mathrm{c}} \mathrm{dm}^{-3}\end{array}$ & $\begin{array}{l}1.37 \\
\mathrm{cmol}_{\mathrm{c}} \mathrm{dm}^{-3}\end{array}$ & $\begin{array}{l}61.33 \\
\mathrm{mg} \mathrm{dm}^{-3}\end{array}$ & $\begin{array}{l}5.02 \\
\mathrm{cmol}_{\mathrm{c}} \mathrm{dm}^{-3}\end{array}$ & $\begin{array}{l}3.62 \\
\mathrm{mg} \mathrm{dm}\end{array}$ & $\begin{array}{l}10.31 \\
\mathrm{cmol}_{\mathrm{c}} \mathrm{dm}^{-3}\end{array}$ & $\begin{array}{l}51.94 \\
\%\end{array}$ \\
\hline SE & - & 0.04 & 0.03 & 1.02 & 0.13 & 0.05 & 5.01 & 0.27 & 0.43 & 0.32 & 1.35 \\
\hline
\end{tabular}

Note. VF: variation factor. LU: land-use. SD: soil depth (SD1 $=0-0.05 \mathrm{~m}, \mathrm{SD} 2=0.10-0.20 \mathrm{~m}, \mathrm{SD} 3=0.20-0.30$ $\mathrm{m})$. $\mathrm{CV}(\%)$. Coefficient of variation. SE: standard error. DF: degree of freedom. $\mathrm{pH}$ : $\mathrm{pH}$ in water. Al: aluminium. SOM: soil organic matter. Ca: calcium. Mg: magnesium. $\mathrm{K}$ : potassium. $\mathrm{H}+\mathrm{Al}$ : potential acidity. P: phosphorus. T: cation exchange capacity. V\%: base saturation. $\mathrm{ns}=$ not significant; * significant $(\mathrm{P}<0.05)$; ** significant $(\mathrm{P}<$ $0.01)$.

Table 4 shows the breakdown of the interaction between the factors of land-use and soil depth for significant physical attributes. For the total clay (TC) attribute, it was found that the pasture use had a lower content in the superficial layers of the soil (0-0.05 and 0.1-0.2 m), as well as in the 0.2-0.30 m layer, however, accompanied by sugarcane. It was found that all land-uses (except pasture 0-0.05 m) had TC values greater than $350 \mathrm{~g} \mathrm{~kg}^{-1}$ and were therefore classified as clayey (Sousa \& Lobato, 2004). In such studies, it is always desirable that the TC 
content be similar between the study areas (Table 4), which indicates their uniformity. However, this result does not always occur, even when working with the same soil class (Gasparetto, Braida, Carneiro, Scariot, \& Tabolka, 2009), which is unfavourable because it is an additional cause of variation between treatments.

Table 4. Selected soil physical attributes of an Oxisol under different land-use and management and soil depths

\begin{tabular}{|c|c|c|c|c|c|c|}
\hline Land-use & $\mathrm{TC}$ & $\mathrm{BD}$ & PD & TP & SRP & GWC \\
\hline & $\mathrm{g} \mathrm{kg}^{-1}$ & -------- 1 & $n^{-3}$-------- & $\%$ & $\mathrm{MPa}$ & $\%$ \\
\hline \multicolumn{7}{|l|}{$0-0.05 \mathrm{~m}$} \\
\hline Annual crops & $499.2 \mathrm{aB}$ & $1.35 \mathrm{aA}$ & $2.49 \mathrm{aA}$ & $46.03 \mathrm{bA}$ & $0.94 \mathrm{aC}$ & $19.76 \mathrm{aA}$ \\
\hline Pasture & $348.4 \mathrm{cB}$ & $1.38 \mathrm{aA}$ & $2.43 \mathrm{aA}$ & $43.34 \mathrm{bB}$ & $0.99 \mathrm{aB}$ & $20.10 \mathrm{aA}$ \\
\hline Sugarcane & $433.8 \mathrm{bA}$ & $1.35 \mathrm{aA}$ & $2.48 \mathrm{aA}$ & $45.43 \mathrm{bA}$ & $2.16 \mathrm{aA}$ & $16.44 \mathrm{bB}$ \\
\hline Native forest & $426.0 \mathrm{bB}$ & $1.09 \mathrm{bA}$ & $2.42 \mathrm{aA}$ & $54.87 \mathrm{aA}$ & $1.33 \mathrm{aB}$ & $21.26 \mathrm{aA}$ \\
\hline \multicolumn{7}{|l|}{$0.1-0.2 \mathrm{~m}$} \\
\hline Annual crops & $495.8 \mathrm{aB}$ & $1.28 \mathrm{aA}$ & $2.57 \mathrm{aA}$ & $50.29 \mathrm{aA}$ & $3.79 \mathrm{aB}$ & $18.32 \mathrm{bA}$ \\
\hline Pasture & $390.0 \mathrm{bB}$ & $1.30 \mathrm{aA}$ & $2.43 \mathrm{bA}$ & $46.40 \mathrm{bB}$ & $3.96 \mathrm{aA}$ & $18.76 \mathrm{bA}$ \\
\hline Sugarcane & $500.6 \mathrm{aA}$ & $1.41 \mathrm{aA}$ & $2.51 \mathrm{aA}$ & $43.78 \mathrm{bA}$ & $3.48 \mathrm{aA}$ & $18.75 \mathrm{bA}$ \\
\hline Native forest & $497.8 \mathrm{aA}$ & $1.10 \mathrm{bA}$ & $2.45 \mathrm{bA}$ & $54.99 \mathrm{aA}$ & $4.39 \mathrm{aA}$ & $22.36 \mathrm{aA}$ \\
\hline \multicolumn{7}{|l|}{$0.2-0.3 \mathrm{~m}$} \\
\hline Annual crops & $520.0 \mathrm{aA}$ & $1.23 \mathrm{bA}$ & $2.54 \mathrm{aA}$ & $51.69 \mathrm{aA}$ & $5.03 \mathrm{aA}$ & $19.75 \mathrm{aA}$ \\
\hline Pasture & $434.4 \mathrm{bA}$ & $1.16 \mathrm{bB}$ & $2.44 \mathrm{bA}$ & $52.19 \mathrm{aA}$ & $3.90 \mathrm{bA}$ & $19.38 \mathrm{aA}$ \\
\hline Sugarcane & $443.8 \mathrm{bA}$ & $1.37 \mathrm{aA}$ & $2.52 \mathrm{aA}$ & $45.36 \mathrm{bA}$ & $3.07 \mathrm{bA}$ & $19.57 \mathrm{aA}$ \\
\hline Native forest & $510.2 \mathrm{aA}$ & $1.06 \mathrm{bA}$ & $2.45 \mathrm{bA}$ & $56.59 \mathrm{aA}$ & $5.28 \mathrm{aA}$ & $20.70 \mathrm{aA}$ \\
\hline
\end{tabular}

Note. TC: total clay. BD: bulk density. PD: particles density. TP: total porosity. SRP: soil resistance to penetration. GWC: gravimetric water content. CV: coefficient of variation. Different lower-case letters in the columns within the same soil depth and upper-case letters in the columns between soil depths differ by the Scott-Knott test $(\mathrm{P}<0.05)$.

Regarding the bulk density (BD), the forest use presented the lowest averages in the superficial layers of the soil $(0-0.05$ and $0.1-0.2 \mathrm{~m})$. This effect possibly occurred due to the absence of traffic and trampling and the continuous accumulation of organic material on the soil (e.g., leaves and branches of plants), which results in increased soil porosity and, consequently, reduces the $\mathrm{BD}$, confirmed by a significant negative correlation between BD and TP (Table 5). These results are corroborated by other authors (Silva, Santos, Silva, \& Souza, 2015; Silva et al., 2017). 
Table 5. Pearson correlation coefficients between selected soil chemical and physical attributes under different land-use and management schemes and at different soil depths

\begin{tabular}{|c|c|c|c|c|c|c|c|c|c|c|c|c|c|c|c|c|}
\hline & $\mathrm{NC}$ & DF & $\mathrm{BD}$ & PD & SRP & TP & $\mathrm{pH}$ & SOM & $\mathrm{Ca}$ & $\mathrm{Mg}$ & $\mathrm{Al}$ & HAl & $\mathrm{T}$ & $\mathrm{K}$ & $\mathrm{P}$ & V\% \\
\hline $\mathrm{NC}$ & 1 & & & & & & & & & & & & & & & \\
\hline DF & $-0.9^{* *}$ & 1 & & & & & & & & & & & & & & \\
\hline $\mathrm{BD}$ & -0.2 & 0.1 & 1 & & & & & & & & & & & & & \\
\hline PD & -0.2 & $0.3^{*}$ & $0.2^{*}$ & 1 & & & & & & & & & & & & \\
\hline SRP & 0.1 & 0.1 & $-0.3^{* *}$ & 0.16 & 1 & & & & & & & & & & & \\
\hline TP & 0.2 & -0.1 & $-0.9^{* *}$ & 0 & $0.4^{* *}$ & 1 & & & & & & & & & & \\
\hline $\mathrm{pH}$ & $0.2^{*}$ & $-0.3^{* *}$ & 0.1 & 0.1 & 0.1 & -0.1 & 1 & & & & & & & & & \\
\hline SOM & 0.2 & $-0.3^{* *}$ & -0.2 & $-0.5^{* *}$ & $-0.3^{*}$ & 0.1 & -0.2 & 1 & & & & & & & & \\
\hline $\mathrm{Ca}$ & $0.4^{* *}$ & $-0.6^{* *}$ & -0.2 & $-0.3^{*}$ & -0.2 & 0.2 & $0.3^{* *}$ & $0.6^{* *}$ & 1 & & & & & & & \\
\hline $\mathrm{Mg}$ & $0.5^{* *}$ & $-0.6^{* *}$ & -0.1 & $-0.2^{*}$ & -0.2 & 0.1 & $0.3^{* *}$ & $0.6^{* *}$ & $0.7^{* *}$ & 1 & & & & & & \\
\hline $\mathrm{Al}$ & -0.1 & 0.2 & $-0.3^{* *}$ & -0.1 & $0.4^{* *}$ & $0.3^{* *}$ & $-0.4^{* *}$ & 0.1 & $-0.2^{*}$ & -0.2 & 1 & & & & & \\
\hline HAl & 0.1 & 0.1 & $-0.5^{* *}$ & $-0.4^{* *}$ & 0.1 & $0.4^{* *}$ & $-0.5^{* *}$ & $0.5^{* *}$ & 0 & 0.2 & $0.6^{* *}$ & 1 & & & & \\
\hline $\mathrm{T}$ & 0.3 & $-0.3^{* *}$ & $-0.5^{* *}$ & $-0.5^{* *}$ & 0.1 & $0.4^{* *}$ & $-0.3^{*}$ & $0.8^{* *}$ & $0.5^{* *}$ & $0.5^{* *}$ & $0.4^{* *}$ & $0.9^{* *}$ & 1 & & & \\
\hline K & -0.1 & 0.2 & 0.1 & $0.3^{*}$ & $-0.3^{* *}$ & -0.1 & $-0.3^{* *}$ & -0.1 & -0.1 & -0.2 & -0.1 & -0.2 & -0.2 & 1 & & \\
\hline $\mathrm{P}$ & 0.1 & 0.1 & $0.2^{*}$ & 0.2 & -0.2 & -0.2 & 0.1 & $-0.3^{*}$ & -0.2 & -0.2 & -0.1 & $-0.2^{*}$ & $-0.3^{*}$ & $0.5^{* *}$ & 1 & \\
\hline $\mathrm{V} \%$ & 0.2 & $-0.4^{* *}$ & $0.3^{*}$ & 0.2 & -0.1 & $-0.2^{*}$ & $0.7^{* *}$ & -0.2 & $0.5^{* *}$ & $0.3^{* *}$ & $-0.6^{*}$ & $-0.8^{* *}$ & $-0.5^{* *}$ & 0.1 & 0.1 & 1 \\
\hline
\end{tabular}

Note. NC: natural clay. DF: degree of flocculation. BD: bulk density. PD: particles density. SRP: soil resistance to penetration. TP: total porosity. $\mathrm{pH}: \mathrm{pH}$ in water. SOM: soil organic matter. Ca: calcium. Mg: magnesium. Al: aluminium. HAl: potential acidity. T: cation exchange capacity. K: potassium. P: phosphorus. V\%: base saturation. * significant $(\mathrm{P}<0.05)$; ** significant $(\mathrm{P}<0.01)$.

At a depth of 0.2-0.3 m, the soil cultivated with sugar cane showed the highest $\mathrm{BD}$, while the other treatments did not differ from the forest. In the cultivation system in which sugarcane is harvested manually and with burning, the traffic of machines is intense due to the various operations carried out. Agricultural machinery traffic increases the BD and decreases the weighted average diameter and the macroporosity in the wheel set line in relation to the planting line, which causes cumulative degradation of the physical quality of the soil over the years of cultivation (Roque, Souza, Barbosa, \& Souza, 2010).

The BD values presented for the sugarcane area are still within the limits considered tolerable by Beulter and Centurion (2004) and Beutler et al. (2005), who indicated values on the order of $1.55 \mathrm{~kg} \mathrm{dm}^{-3}$ as critical for soils with a clayey texture. This increase in BD can also be explained by the reduction in the content of organic matter in the soil (SOM) in comparison with the forest use. At all depths evaluated, the forest use had a higher SOM content (Table 6). 
Table 6: Selected soil chemical attributes of an Oxisol under different land-use and management schemes and at different soil depths.

\begin{tabular}{|c|c|c|c|c|c|c|c|c|c|}
\hline LU & $\mathrm{Al}$ & $\mathrm{Ca}$ & $\mathrm{Mg}$ & $\mathrm{H}+\mathrm{Al}$ & $\mathrm{T}$ & SOM & $\mathrm{V} \%$ & $\mathrm{P}$ & $\mathrm{K}$ \\
\hline & \multicolumn{5}{|c|}{ 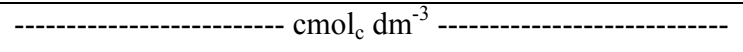 } & \multicolumn{2}{|c|}{------------ \% ----------- } & \multicolumn{2}{|c|}{$-----\mathrm{mg} \mathrm{dm}^{-3}----$} \\
\hline \multicolumn{10}{|c|}{$0-0.05 \mathrm{~m}$} \\
\hline $\mathrm{AC}$ & $0.21 \mathrm{aA}$ & $3.46 \mathrm{bA}$ & $1.15 \mathrm{bA}$ & $4.80 \mathrm{bA}$ & $9.76 \mathrm{bA}$ & $21.20 \mathrm{bA}$ & $50.75 \mathrm{aA}$ & $9.58 \mathrm{aA}$ & $138 \mathrm{aA}$ \\
\hline $\mathrm{P}$ & $0.10 \mathrm{aA}$ & $4.01 \mathrm{bA}$ & $1.73 \mathrm{aA}$ & $4.92 \mathrm{bA}$ & $10.80 \mathrm{bA}$ & $35.04 \mathrm{aA}$ & $52.36 \mathrm{aA}$ & $2.58 \mathrm{bA}$ & $48 \mathrm{bA}$ \\
\hline $\mathrm{SC}$ & $0.14 \mathrm{aA}$ & $3.97 \mathrm{bA}$ & $1.55 \mathrm{aA}$ & $4.34 \mathrm{bA}$ & $10.08 \mathrm{bA}$ & $21.56 \mathrm{bA}$ & $56.69 \mathrm{aA}$ & $3.06 \mathrm{bA}$ & $78 \mathrm{bA}$ \\
\hline $\mathrm{NF}$ & $0.22 \mathrm{aB}$ & $5.27 \mathrm{aA}$ & $1.83 \mathrm{aA}$ & $6.84 \mathrm{aB}$ & $14.10 \mathrm{aA}$ & $35.50 \mathrm{aA}$ & $51.46 \mathrm{aA}$ & $2.26 \mathrm{bA}$ & $58 \mathrm{bA}$ \\
\hline \multicolumn{10}{|c|}{$0.1-0.2 \mathrm{~m}$} \\
\hline $\mathrm{AC}$ & $0.16 \mathrm{bA}$ & $3.31 \mathrm{aA}$ & $1.12 \mathrm{aA}$ & $3.94 \mathrm{bA}$ & $8.60 \mathrm{bB}$ & $17.44 \mathrm{bA}$ & $54.11 \mathrm{aA}$ & $6.20 \mathrm{aB}$ & $86 \mathrm{aB}$ \\
\hline$P$ & $0.18 \mathrm{bA}$ & $4.17 \mathrm{aA}$ & $1.26 \mathrm{aB}$ & $4.12 \mathrm{bA}$ & $9.64 \mathrm{bA}$ & $25.84 \mathrm{aB}$ & $57.07 \mathrm{aA}$ & $1.74 \mathrm{bA}$ & $40 \mathrm{bA}$ \\
\hline $\mathrm{SC}$ & $0.07 \mathrm{bA}$ & $3.37 \mathrm{aA}$ & $1.43 \mathrm{aA}$ & $3.38 \mathrm{bA}$ & $8.30 \mathrm{bB}$ & $16.22 \mathrm{bB}$ & $58.85 \mathrm{aA}$ & $1.90 \mathrm{bA}$ & $42 \mathrm{bB}$ \\
\hline NF & $0.38 \mathrm{aB}$ & $3.45 \mathrm{aB}$ & $1.43 \mathrm{aA}$ & $8.56 \mathrm{aA}$ & $13.88 \mathrm{aA}$ & $26.38 \mathrm{aB}$ & $36.22 \mathrm{bB}$ & $1.78 \mathrm{bA}$ & $40 \mathrm{bA}$ \\
\hline \multicolumn{10}{|c|}{$0.2-0.3 \mathrm{~m}$} \\
\hline $\mathrm{AC}$ & $0.25 \mathrm{bA}$ & $3.46 \mathrm{aA}$ & $1.09 \mathrm{aA}$ & $3.58 \mathrm{bA}$ & $8.00 \mathrm{cB}$ & $14.88 \mathrm{bA}$ & $55.30 \mathrm{aA}$ & $5.18 \mathrm{aB}$ & $84 \mathrm{aB}$ \\
\hline $\mathrm{P}$ & $0.14 \mathrm{bA}$ & $4.03 \mathrm{aA}$ & $1.15 \mathrm{aB}$ & $3.96 \mathrm{bA}$ & $9.36 \mathrm{bA}$ & $22.48 \mathrm{aB}$ & $56.40 \mathrm{aA}$ & $2.12 \mathrm{bA}$ & $52 \mathrm{bA}$ \\
\hline $\mathrm{SC}$ & $0.07 \mathrm{bA}$ & $2.91 \mathrm{aA}$ & $1.34 \mathrm{aA}$ & $3.00 \mathrm{bA}$ & $7.34 \mathrm{cB}$ & $13.34 \mathrm{bB}$ & $58.87 \mathrm{aA}$ & $5.30 \mathrm{aA}$ & $32 \mathrm{bB}$ \\
\hline $\mathrm{NF}$ & $0.69 \mathrm{aA}$ & $3.31 \mathrm{aB}$ & $1.41 \mathrm{aA}$ & $8.78 \mathrm{aA}$ & $13.84 \mathrm{aA}$ & $26.00 \mathrm{aB}$ & $35.13 \mathrm{bB}$ & $1.68 \mathrm{bA}$ & $38 \mathrm{bA}$ \\
\hline
\end{tabular}

Note. LU: land-use. AC: annual crops. P: pasture. SC: sugarcane. NF: native forest. Al: aluminium. Ca: calcium. $\mathrm{Mg}$ : magnesium. $\mathrm{H}+\mathrm{Al}$ : potential acidity. $\mathrm{T}$ : cation exchange capacity. SOM: soil organic matter. $\mathrm{V} \%$ : base saturation. P: phosphorus. K: potassium. CV: coefficient of variation. Different lower-case letters in the columns within the same soil depth and upper-case letters in the columns between soil depths differ by the Scott-Knott test $(\mathrm{P}<0.05)$.

Regarding the particle density (PD), higher values can be verified for the areas of sugar cane and annual crops (Table 4), at depths of 0.1-0.2 and 0.2-0.3 m. There was no significant variation in PD at different depths for the same type of use. Silva, Costa, Barbosa, Martins, and Pereira (2013), working with the same type of soil as the present study, also obtained lower Dp values for pasture and forest uses. According to Morais, Pissarra and Reis (2012), the density of the MOS is lower than that of the mineral fraction, and thus, the SOM influences the PD of the soil, leading to its reduction.

The total porosity (TP) under forest use was greater than that under other land-uses at depths of 0-0.05 $\mathrm{m}$ and, together with the use of annual crops, also at a depth of 0.1-0.2 m. At a depth of 0.2-0.3 m, the use of sugarcane had the lowest average, with no differences between the other land-uses. Only the pasture area showed significant differences between depths, where lower TP values were observed within the first $20 \mathrm{~cm}$, which is possibly related to the higher BD found in this layer. The results found by the present study corroborate those of Tormena, Vidigal Filho, Gonçalves, Araújo and Pintro (2004) for total porosity (TP), being lower in the uses of cane, pasture and crops compared with the forest area.

Regarding the SRP, there were only differences between land-uses at a depth of 0.2-0.3 m, where native forest and annual crops presented the highest averages. This is probably due to the "grid foot" resulting from the conventional tillage system in the area of annual crops, and due to the effect of the greater amount of thick roots in the forest area, as they present similar humidity (GWC) at that depth (Table 4). In the 0-0.05 m layer, the SRP values were lower than the critical level $(>2 \mathrm{MPa})$ except for cane use. In the deepest layers (0.1-0.2 and 0.2-0.3 $\mathrm{m})$, in all types of uses, it can be noted that the values are higher than the limit considered critical characterizing soil compaction. These results corroborate those found by Oliveira, Rocha, Rocha and Fiorillo (2010).

Table 6 shows the breakdown of the chemical attributes of the soil that showed a significant difference for the use $\mathrm{x}$ depth interaction. In the 0-0.05 m layer of exchangeable aluminium content (Al), there were no difference between the evaluated land-uses; however, in the subsequent layers (0.1-0.2 and 0.2-0.3 m), the content of $\mathrm{Al}$ was lower than in the forest. The lower values of $\mathrm{Al}$ in annual crops and sugarcane uses may be related to the residual effect of soil correction carried out with the application of limestone. Several studies show that limestone has a residual effect that persists for several years (Cravo, Smyth, \& Brasil, 2012; Natale, Rozane, Parent, \& Parent, 2012; Wang, Tang, Baldock, Butterly, \& Gazey, 2016).

As for the calcium content in the soil (Ca), there were only differences between land-uses at a depth of 0-0.05 m, where the forest showed the highest average. It was also found that the forest use showed lower levels of Ca in 
the layers of 0.1-0.2 and 0.2-0.3 m. The higher content of this element in the forest use is probably related to the greater release due to the deposition and decomposition of litter. In relation to magnesium $(\mathrm{Mg})$, there were only differences between land-uses in the 0-0.05 m layer, where annual crops showed the highest average. There was only a depth effect of the land on pasture use, with a higher content of this nutrient in the 0-0.05 m layer, which may be related to the deposition and decomposition of grass residues. The Mg content is positively correlated with the soil organic matter (SOM) content (Table 5), according to previous studies (Triantafyllidis, Kosma, \& Patakas, 2018).

The SOM content was influenced by both land-use and depth (Table 6). SOM was lower in sugarcane uses and annual crops at all depths evaluated. The lower SOM content under these two land-uses is directly related to soil management and the type of harvest (burning the cane field), which contribute to reducing SOM over time, as noted by Mendonza et al. (2000).

As expected, there was a higher content in the $0-0.05 \mathrm{~m}$ layer and a reduction in the SOM content with increasing soil depth for all soil uses (except annual crops). This is related to the higher surface deposition of plant and animal waste, which was also observed by Centurion, Cardoso, and Natale (2001) and Wendling, Jucksch, Mendonça and Neves (2005) and with the highest concentration of plant roots on the surface (Oliveira et al., 2009).

In relation to base saturation (V\%), there were differences between land-uses at depths of 0.1-0.2 and 0.2-0.3 m, where forest use had the lowest average. Among soil depths, there were differences only for forest use, where the 0-0.05 m layer presented the highest average. This absence of differences between cultivated areas may be associated with the use of fertilizers and acidity correctives, which allow neutralization of $\mathrm{H}$ and $\mathrm{Al}$ and increase the availability of bases (Hunke et al., 2014). The V\% values ranged from $35 \%$ to $58 \%$, which are considered adequate for these land-uses (Sousa \& Lobato, 2004).

Regarding the total cation exchange capacity $(\mathrm{T})$, the values found for the forest area were higher than those of other land-uses at all depths studied (Table 6). The areas under annual crops and sugarcane showed a reduction in $\mathrm{T}$ values with increasing soil depth. These results confirm that the absence of soil disturbance allows conservation of the physical and chemical properties of the soil (e.g., T), which are directly related to the conservation of the SOM, which reaches up to $90 \%$ of the soil T (Novais, Smyth, \& Nunes, 2007), according to a positive correlation $(\mathrm{P}<0.05)$ between SOM and $\mathrm{T}$ (Table 5).

The phosphorus $(\mathrm{P})$ content was higher in all depths evaluated when using annual crops, and at a depth of 0.2-0.3 $\mathrm{m}$, the $\mathrm{P}$ content in sugarcane use did not differ from that of annual crops. This was due to the adopted fertility management strategy, with frequent fertilization and little mobility of this element. In the case of soil under sugar cane cultivation, the higher $\mathrm{P}$ content is probably associated with the deeper application with a furrow/fertilizer in planting cane with reforestation of the cane field. It was found that the forest area showed higher values of potential acidity $(\mathrm{H}+\mathrm{Al})$ than other land-uses at all depths studied (Table 6). SOM has several functional groups, especially the carboxylic and phenolic groups, which release the $\mathrm{H}$ that will constitute the ions of the soil cation exchange capacity. According to Cardoso, Silva, Curi, Ferreira and de Freitas (2011), this indicates that SOM can be an important source of potential acidity in tropical soils, especially in environments where litter accumulation occurs. Similar results were also found by Portugal, Costa and Costa (2010), with higher values observed in the use of forest $\left(9.38\right.$ and $\left.8.45 \mathrm{cmolc} \mathrm{dm}^{-3}\right)$, indicating that these values are related to the highest levels of SOM. Santos, Marchão, Silva, Silveira and Becquer (2011) also observed higher levels of H+Al in native forest in relation to pasture.

Regarding potassium $(\mathrm{K})$, it is observed that the use of annual crops presented values significantly higher than the other uses studied (Table 6), which can be explained by the residual effect of applications according to the history of use of the area. The K contents in the 0-0.05 m layer under the annual crops and sugarcane uses are considered high, while under pasture, average levels prevail (Sousa \& Lobato, 2004). At the other depths, all land-uses (except annual crops) showed average $\mathrm{K}$ levels, indicating that fertility management must be adjusted through cultural practices.

\section{Conclusion}

Under the conditions of the study, the use of sugarcane reduces the physical and chemical quality of the studied soil $(>\mathrm{BD},<\mathrm{TP},>\mathrm{SRP},<\mathrm{SOM},<\mathrm{T}$ and $<\mathrm{P})$, followed by annual crops $(>\mathrm{SRP},<\mathrm{Mg},<\mathrm{SOM}$ and $<\mathrm{T})$ and pasture $(<\mathrm{TP}$ and $<\mathrm{P})$. There is a deep gradient for the attributes $\mathrm{SOM}, \mathrm{Mg}, \mathrm{T}, \mathrm{P}$ and $\mathrm{K}$ associated with the use of sugarcane, annual crops and pasture related to soil and fertility management and the dynamics of nutrients. The non-disturbance of the soil as occurs in the use of land for pasture appears to be one of the appropriate practices in the search for maintenance of the physical and chemical quality of Oxisols in the studied watershed. 


\section{Acknowledgements}

To the Goiano Federal Institute for the financial support to conduct the study.

\section{References}

Beulter, A. N., \& Centurion, J. F. (2004). Compactação do solo no desenvolvimento radicular e na produtividade da soja. Pesquisa Agropecuária Brasileira, 39, 581-588. https://doi.org/10.1590/S0100-204X2004000 600010

Beutler, A. N., Centurion, J. F., Roque, C. G., \& Ferraz, M. V. (2005). Densidade relativa ótima de Latossolos Vermelhos para a produtividade de soja. Revista Brasileira de Ciência do Solo, 29, 843-849. https://doi.org/ 10.1590/S0100-06832005000600002

Bonetti, J. A., Paulino, H. B., Souza, E. D., Carneiro, M. A. C., \& Caetano, J. O. (2018). Soil physical and biological properties in an integrated crop-livestock system in the Brazilian Cerrado. Pesquisa Agropecuária Brasileira, 53, 1239-1247. https://doi.org/10.1590/s0100-204x2018001100006

Cardoso, E. L., Silva, M. L. N., Curi, N., Ferreira, M. M., \& de Freitas, D. A. F. (2011). Qualidade química e física do solo sob vegetação arbórea nativa e pastagens no Pantanal Sul-Mato-Grossense. Revista Brasileira de Ciência do Solo, 35, 613-622. https://doi.org/10.1590/S0100-06832011000200030

Centurion, J. F., Cardoso, J. P., \& Natale, W. (2001). Efeito de formas de manejo em algumas propriedades físicas e químicas de um Latossolo Vermelho em diferentes agroecossistemas. Revista Brasileira de Engenharia Agrícola e Ambiental, 5, 254-258. https://doi.org/10.1590/S1415-43662001000200013

Cravo, M. S., Smyth, T. J., \& Brasil, E. C. (2012). Calagem em latossolo amarelo distrófico da amazônia e sua influência em atributos químicos do solo e na produtividade de culturas anuais. Revista Brasileira de Ciência do Solo, 36, 895-908. https://doi.org/10.1590/S0100-06832012000300020

Day, P. R. (1965). Particle fractionation and particle-size analysis. In C. A. Black (Ed.), Methods soil analysis. Madison: American Society of Agronomy.

Dias, F. P. M., Hübner, R., Nunes, F. J., Leandro, W. M., \& Xavier, F. A. S. (2019). Effects of land-use change on chemical attributes of a Ferralsol in Brazilian Cerrado. Catena, 177, 180-188. https://doi.org/10.1016/ j.catena.2019.02.016

Donagema, G. K., Campos, D. V. B., Calderano, S. B., Teixeira, W. G., \& Viana, J. H. M. (2011). Manual de métodos de análise de solo (2nd ed.). Rio de Janeiro, RJ: Embrapa Solos.

Gasparetto, E. C., Braida, J. A., Carneiro M., Scariot, J. J., \& Tabolka, C. L. (2009). Grau de floculação da argila de um Latossolo Vermelho utilizado com lavoura e mata nativa. Synergismus Scyentifica UTFPR, 4, 357-359.

Hunke, P., Mueller, E. N., Schröder, B., \& Zeilhofer, P. (2014). The Brazilian Cerrado: assessment of water and soil degradation in catchments under intensive agricultural use. Ecohydrology, 8, 1154-1180. https://doi.org/ $10.1002 /$ eco. 1573

Hunke, P., Roller, R., Zeilhofer, P., Schröder, B., \& Mueller, E. N. (2015). Soil changes under different land-uses in the Cerrado of Mato Grosso, Brazil. Geoderma Regional, 4, 31-43. https://doi.org/10.1016/j.geodrs. 2014.12.001

Lobato, M. G. R., Sampaio F. M. T., Nóbrega, J. C. A., Ferreira, M. M., Matias, S. S. R., Torres, A. F., Silva C. P. \& Cunha, C. S. M. (2018). Physical atributes of a oxisol from the brazilian cerrado under different management systems. Journal of Agricultural Science, 10, 361-368. https://doi.org/10.5539/jas.v10n1p361

Marques, V. S. (2013). Erosão hídrica em microbacia utilizando geotecnologias (Doctoral dissertation, Universidade Federal Rural do Rio de Janeiro, Seropédica, Brazil). Retrieved from https://tede.ufrrj.br

Mendonza, H. N. S., Lima, E., Anjos, L. H. C., Silva, L. A., Ceddia, M. B. \& Antunes, M. V. M. (2000). Propriedades químicas e biológicas de solo de tabuleiro cultivado com cana-de-açúcar com e sem queima da palhada. Revista Brasileira de Ciência do Solo, 24, 201-207. https://doi.org/10.1590/S0100-06832 000000100022

Moklyachuk, L., Yatsuk, I., \& Draga, M. (2015). A monitoring study of soil fertility in the agricultural area of Rivne region of Uukraine. Emirates Journal of Food and Agriculture, 27, 221-230. https://doi.org/10.9755/ ejfa.v27i2.19278 
Morais, T. P. S., Pissarra, T. C. T., \& Reis, F. C. (2012). Atributos físicos e matéria orgânica de um Argissolo Vermelho-amarelo em microbacia hidrográfica sob vegetação nativa, pastagem e cana-de-açúcar. Enciclopédia Biosfera, 8, 214-223.

Natale, W., Rozane, D. E., Parent, L. E., \& Parent, S. É. (2012). Acidez do solo e calagem em pomares de frutíferas tropicais. Revista Brasileira de Fruticultura, 34, 1294-1306. https://doi.org/10.1590/S0100-2945 2012000400041

Novais, R. F., Smyth, T. J., \& Nunes, F. N. (2007). Fertilidade do solo. Viçosa, MG: SBCS.

Oliveira, F. S., Varajão, A. F. D. C., Varajão, C. A. C., Boulangé, B., Costa, J. L. G., \& Vessani, L. A. (2009). Alteração supergênica e morfogênese tropical no complexo máfico-ultramáfico acamadado de Barro Alto, GO. Geociências, 28, 255-272.

Oliveira, R. T., Rocha, L. C. D., Rocha, I. G., \& Fiorillo, C. A. L. (2010). Caracterização física dos solos sob diferentes usos. Revista Agrogeoambiental, 2, 1-8. https://doi.org/10.18406/2316-1817v2n12010246

Pilatti, M. A., Secco, D., Zanão Jr., L. A., Marins, A. C. de, Tokura L. K., \& Villa, B. de. (2018). Structural alterations of Paraná's oxisols by cover crops. Journal of Agricultural Science, 10, 180-190. https://doi.org/ 10.5539 /jas.v10n9p 180

Portugal, A. F., Costa, O. D. A. V., \& Costa, L. M. (2010). Propriedades físicas e químicas do solo em áreas com sistemas produtivos e mata na região da zona da mata mineira. Revista Brasileira de Ciência do Solo, 34, 575-585. https://doi.org/10.1590/S0100-06832010000200032

Roque, A. A. O., Souza, Z. M., Barbosa, R. S., \& Souza, G. S. (2010). Controle de tráfego agrícola e atributos físicos do solo em área cultivada com cana-de-açúcar. Pesquisa Agropecuária Brasileira, 45, 744-750. https://doi.org/10.1590/S0100-204X2010000700016

Santos, G. G., Marchão, R. L., Silva, E. M., Silveira, P. M., \& Becquer, T. (2011). Qualidade física do solo sob sistemas de integração lavoura-pecuária. Pesquisa Agropecuária Brasileira, 46, 1339-1348. https://doi.org/ 10.1590/S0100-204X2011001000030

Silva, G. F., Santos, D., Silva, A. P., \& Souza, J. M. (2015). Indicadores de qualidade do solo sob diferentes sistemas de uso na mesorregião do agreste paraibano. Revista Caatinga, 28, 25-35. https://doi.org/10.1590/ $1983-21252015 \mathrm{v} 28 \mathrm{n} 303 \mathrm{rc}$

Silva, P. C., Costa, R. A., Barbosa, K. F., Martins, Y. A. M., \& Pereira, C. B. J. (2013). Propriedades físicas indicadoras da qualidade do solo sob diferentes culturas e sistemas de manejo no sudoeste goiano. Enciclopédia Biosfera, 9, 2201-2212.

Silva, R. F., Santos, G. G., Nobrega, J. C. A., Oliveira, G. C., Dias, B. D., Santos, D. P., \& Silva Júnior, J. P. da. (2017). Impacts of land-use and management systems on organic carbon and water-physical properties of a Latossolo Amarelo (Oxisol). Semina Ciências Agrárias, 38, 109-124.

Soil Survey Staff. (2014). Keys to soil taxonomy (12th ed.) Washington: USDA-Natural Resources Conservation Service.

Sousa, D. M. G., \& Lobato, E. (2004). Cerrado: Correção do solo e adubação. Brasília, DF: Embrapa Informação Tecnológica.

Tormena, C. A., Vidigal Filho, P. S., Gonçalves, A. C. A., Araújo, M. A., \& Pintro, J. C. (2004). Influência de diferentes sistemas de preparo do solo nas propriedades físicas de um Latossolo Vermelho distrófico. Revista Brasileira de Engenharia Agrícola e Ambiental, 8, 65-71. https://doi.org/10.1590/S1415-43662004 000100010

Triantafyllidis, V., Kosma, A. K. C., \& Patakas, A. (2018). An assessment of the soil quality index in a mediterranean agro ecosystem. Emirates Journal of Food and Agriculture, 30, 1042-1050. https://doi.org/ 10.9755/ejfa.2018.v30.i12.1886

Wang, X., Tang, C., Baldock, J. A., Butterly, C. R., \& Gazey, C. (2016). Long-term effect of lime application on the chemical composition of soil organic carbon in acid soils varying in texture and liming history. Biology and Fertility of Soils, 52, 295-306. https://doi.org/10.1007/s00374-015-1076-2

Wendling, B., Jucksch, I., Mendonça, E. S., \& Neves, J. C. L. (2005). Carbono orgânico e estabilidade de agregados de um Latossolo Vermelho sob diferentes manejos. Pesquisa Agropecuária Brasileira, 40, 487-494. https://doi.org/10.1590/S0100-204X2005000500010 


\section{Copyrights}

Copyright for this article is retained by the author(s), with first publication rights granted to the journal.

This is an open-access article distributed under the terms and conditions of the Creative Commons Attribution license (http://creativecommons.org/licenses/by/4.0/). 